\title{
Postmortem findings on a group of Pica pica (Passeriformes: Corvidae)
}

\author{
Ahmet Onur GİRIŞGiN ${ }^{1}$, Aylin ALASONYALILAR DEMIRER ${ }^{2}$, Esra BÜYÜKCANGAZ ${ }^{3}$, \\ Mohammed KHIDER ${ }^{3}$, Sezen BİRLIK ${ }^{4}$, Volkan İPEK ${ }^{2}$
}

Bursa Uludağ University, ${ }^{1}$ Veterinary Faculty, Department of Parasitology, Bursa; ${ }^{2}$ Department of Pathology, Bursa; ${ }^{3}$ Department of Microbiology, Bursa; ${ }^{4}$ Science Faculty, Department of Biology, Bursa, Turkey.

\begin{abstract}
Summary: Common magpies (Corvidae: Pica pica) distribute through rural and urban areas of Turkey. Because of their distribution in urbanised regions, magpies may have some potential infectious agents which may relate to domestic animals and humans. In this study, eight common magpies brought to the animal hospital in need of medical intervention were examined for endoparasites and bacteria in a one-year period. Additionally, histopathologic examinations with related organs were carried out along with endo-parasitical, cytological and microbial examination the following necropsy. As results of the necropsies, three parasite species including two helminths and one protozoan (Passerilepis sp., Brachylaima sp., Isospora rochalimai, respectively) were identified, while Staphylococcus xylosus, S. sciuri, Escherichia coli, Klebsiella pneumonia, Salmonella spp. were isolated after microbiological examination. Histopathology revealed that subacute focal mycotic pneumonia, chronic nonpurulent granulomatous gastroenteritis, verminous enteritis, and the presence of paratyphoid nodules in liver. Both of the parasites and bacteria are the first records for Turkey's helminth/bacterial fauna in wild birds.
\end{abstract}

Keywords: Bacteria, endoparasites, histopathology, magpie, Pica pica

\section{Bir grup Pica pica'da (Passeriformes: Corvidae) posmortem bulgular}

Özet: Saksağan (Corvidae: Pica pica), Türkiye'nin kırsal ve şehirleşmiş alanlarında yaygın olarak bulunan bir kuş türüdür. Bu kuşlar şehirleşmiş alanlarda bulunduklarından dolayı, evcil hayvanlar ve insanlarla ilişkili bazı enfeksiyöz etkenleri taşıma potansiyeline sahip olabilmektedir. Bu durumu belirlemek için, bir yıl süresince tıbbi bakıma muhtaç bir halde hayvan hastanesine getirilen sekiz adet saksağan, iç parazitler ve bakteriler yönünden muayene edilmiştir. Yapılan nekropside iç parazitik, sitolojik ve mikrobiyal muayeneyi takiben, ilave olarak ilgili organlarda histopatolojik muayeneler de yapılmıştır. Nekropsiler sonucunda, iki helmint ve bir protozoondan oluşan üç tür parazit (sırasıyla Passerilepis sp., Brachylaima sp. ve Isospora rochalimai) teşhis edilmiş ve beş tür bakteri izole edilmiştir (Staphylococcus xylosus, S. sciuri, Escherichia coli, Klebsiella pneumonia, Salmonella spp.). Histopatolojide subakut fokal mikotik pnömoni, kronik nonpurulent granulomatöz gastroenteritis, verminöz enteritis ve karaciğerde paratifoid nodüllerin varlı̆̆ı gözlenmiştir. Belirlenen bu enfeksiyöz etkenler, diğer hayvanlar ve insanlar için potansiyel bir kontaminasyon kaynağı teşkil edebilmektedir. Tespit edilen tüm parazit ve bakteriler, Türkiye'nin yabani kuşlarının helmint ve bakteri faunası için ilk defa bildirilmektedir.

Anahtar sözcükler: Bakteri, histopatoloji, iç parazitler, Pica pica, saksağan

\section{Introduction}

Common Magpie, Pica pica, is a resident breeding bird throughout Europe, much of Asia, northwestern of North America and northwest Africa. They are common in suburban areas and can live towards with human (15).

Magpies are omnivorous, eating young birds and eggs, insects, scraps and carrion, acorns, grain and other vegetable substances. As a result of these dietary habits, it is likely that they are frequently exposed to larval or adult parasites. Several fatal/nonfatal parasitological and microbial infections can sometimes affect wild birds.
Coccidiosis is probably one of the most important parasitic diseases of birds both in wild birds, poultry and free-ranging birds. There are numerous species of Isospora for which their entire life cycle is restricted to the intestinal epithelium of their avian hosts and most of the species of Isospora are host specific (13). Approximately 140 species of enteric Isospora have been reported from a wide variety of avian families (10). While most helminths infect wild birds without causing much damage, massive infections can result in reduced performance and increased mortality (18). Helminth infections are generally detected 
during the necropsy of wild birds that die of other diseases, illegal hunting or starvation under severe climate conditions.

Microbial infections are common in free-living wild animals and might act as a reservoir and represent a potential risk for human health. Birds of prey were considered to be a natural reservoir of Staphylococcus aureus and coagulase-negative staphylococci $(21,30)$. Methicillin-resistant Staphylococcus aureus (MRSA) is getting a considerable challenge in livestock and domestic animal species (1).

This study aimed to determine the parasitic/infectious agents according to post-mortem findings of eight Eurasian magpies.

\section{Materials and Methods}

This study was conducted at the Animal Hospital of Uludag University in Bursa, Turkey between May 2015 and May 2016. Bursa is a mountainous province with a surface area of $10,891 \mathrm{~km}^{2}$ that is covered with natural forest. This region is also generally quite humid (average humidity of 69\%) due to the proximity of the Marmara Sea (2).

Ethical committee approval (No: 2015 - 06 / 03) for applications and investigation (Date: 29-06-2015, No: 138216) on birds has been obtained from Uludag University Local Ethical Committee and Ministry of Forestry and Water Affairs of Turkey, respectively.

All of the birds examined in this study were wounded or sick when they reached the hospital, but they died in spite of the medical interventions in the clinics.

In total, eight dead Eurasian magpies (Pica pica) (Figure 3A) were examined for endo-parasites, microbial infections and pathological findings.

Oral cavity, oesophagus, larynx and trachea were examined by making longitudinal incision following gross body inspection. A transverse skin incision across the middle of the abdomen was performed and the thoracoabdominal cavity was opened. The trachea, oesophagus, proventriculus, small intestine, large intestine of each bird were extracted separately for endoparasites. The contents of each organ were sieved through a $100 \mu \mathrm{m}$ aperture sieve, and the residue was transferred to Petri dishes and examined under a stereo microscope. Additionally, the mucosa of the gastrointestinal organs was examined with a stereomicroscope to determine for the presence of helminths. All of the helminths obtained from the intestines were counted. Cestodes and trematodes were fixed in $70 \%$ ethanol, regressively stained with hematoxylin and mounted in balsam for examination. All helminths were identified under a light microscope according to the figures and descriptions presented by Bray et al. (5), Gibson et al. (11), Schmidt (26), Tolgay (33) and Yamaguti $(36,37)$. Finally, representative helminth specimens were deposited in the helminth collection of Uludag University Science Faculty, Bursa, Turkey.

Faecal examination detected the presence of eggs or oocysts based on flotation from samples obtained directly from the intestines. Oocyst positive stool samples were allowed to sporulate and were speciated morphologically. To facilitate sporulation, filtrates were mixed with potassium dichromate $\left(\mathrm{K}_{2} \mathrm{Cr}_{2} \mathrm{O}_{7}\right)$ to a final concentration of $2 \%$ and kept at room temperature for a week. To ensure good oxygenation during sporulation, the oocyst suspension was never more than $50 \mathrm{ml}$, and the containers were agitated daily. Differentiation of species was based on specific morphological features of the sporulated oocyst (size, shape, colour, presence or absence of micropylar cap), the shape of sporocysts and disposition of sporozoites in the sporocysts $(3,35)$.

Samples of brain, trachea, oesophagus, lung, heart, liver, spleen, proventriculus, ventriculus, kidney, small and large intestine were collected and fixed in 10\% phosphate-buffered formalin for pathologic examination. The tissues were embedded in paraffin and they were sectioned at $5 \mu \mathrm{m}$ thickness and stained with hematoxylin and eosin (H\&E) and Grocott's methenamine silver stains. In the gross examination, some magpies had hyperaemic/haemorrhagic intestinal mucosa, touch imprint samples and a smear of intestinal content were prepared from different parts of small intestines and stained with Hemacolor staining kit (Merck) and examined with a light microscope.

The microbiological investigation was designed for the routine diagnosis of the specimens. All freshly collected internal organs (lung, liver, heart and spleen) taken from magpie were pooled together in $50 \mathrm{ml}$ sterile vial within $10 \mathrm{ml}$ of PBS. The internal organs were homogenized with an Ultra-Turrax Micra RT-D9 (ART Prozess \& Labortechnik). The pooled suspension was inoculated on to Columbia agar (COS 43041; bioMérieux) with 7 per cent defibrinated sheep blood, Mac Conkey's Agar (CM115; Oxoid) and Levine Eosine Methylene Blue Agar (CM0069B; Oxoid) for routine diagnosis. Subsequently, all samples were inoculated directly on to Sabouraud Dextrose Agar for fungi (CM0041B; Oxoid), incubated at $25^{\circ} \mathrm{C}$ and $37^{\circ} \mathrm{C}$ in the dark for a minimum of three weeks, and examined weekly for evidence of fungal growth $(22,23)$. All samples were also streaked onto Mycoplasma agar base (CM0401B; Oxoid) containing Mycoplasma supplement G (SR0059C; Oxoid), were incubated for seven days at $37^{\circ} \mathrm{C}$ in a humidified atmosphere with 5 percent $\mathrm{CO}_{2}$. Mycoplasma plates were examined after the seventh day of the incubation under 35 $\times$ magnifications for the typical 'fried egg' appearance.

An enrichment procedure was implemented according to De Boer et al. (7) without second step 
enrichment procedure for the detection of $S$. aureus. Swabs were then placed into a Mueller Hinton Broth (Oxoid CM0405) containing 6.5\% NaCl (Merck K37303004 -721) individually and incubated aerobically at $37^{\circ} \mathrm{C}$ for $24 \mathrm{~h}$. A loopful of culture was then streaked onto Baired Parker Agar (Oxoid CM 961) containing 5\% Egg Yolk Tellurite Emulsion (Oxoid - SR0054C) and incubated for $48 \mathrm{~h}$ in aerobic conditions. Suspected colonies were evaluated by API-Staph ${ }^{\circledR}$ and API-20E ${ }^{\circledR}$ (Biomérieux, Lyon, France) commercial test panels and the results received by API-Web ${ }^{\circledR}$ according to the manufacturer's guideline.

\section{Results}

Two helminthic species were identified, including one Cestoda species Passerilepis sp. (6 adults) on one bird (12.5\%) and one Trematode species Brachylaima sp. (5 adults) (Fig.1) on one bird (12.5\%) (Table 1). Helminths were free in the intestinal lumen when they were detected during necropsy. Both of these helminths are the first record for Turkey's helminth fauna.

Sporulated oocysts obtained from the sporulation assay measured $20.35 \mu \mathrm{m} \times 22.22 \mu \mathrm{m}$ (ranging from 18.76 $-21.59 \mu \mathrm{m} \times 21.69-25.24 \mu \mathrm{m})$ and a shape index (length/width) of $1.08(1.03-1.16)$. Coccidial infection was detected on one bird $(12.5 \%)$ and identified as Isospora rochalimai (Fig. 2). This coccidian species is also recorded for the first time in Turkey.

At necropsy, a 2-mm-diameter inflammatory focus located on lung parenchyma was observed in magpie 1 . In
Magpie 3, dehydration, emaciation, splenomegaly, and hyperemia of the duodenum were observed (Fig. 3B). The pectoral muscle was weak and miliary necrosis foci on the liver were seen in magpie 6. At the cytological exam, many oocysts and coccobacilli were present in intestinal smears from magpie 3 (Fig. 3C). No oocyst was found in smears from magpie 1,2 and 6 . No significant macroscopic findings were observed in magpies 2, 4, 5, 7 and 8. In histopathologic examination, a granuloma is characterized by central necrosis surrounded by degenerate heterophil leucocytes, large number of macrophages and lymphocytes in magpie 1 . Some alveoli are filled with heterophils. There are positive staining of fungal hyphae in green background in Grocott's methenamine silver staining of the lung. Furthermore, diffuse mononuclear inflammatory cells were observed in lamina propria of the small intestine in magpie 1. One cestoda (Passerilepis sp.) was observed in proventriculus lumen in magpie 2, microscopically. An intestinal granuloma characterising by centrally located necrosis, foreign body giant cells and mononuclear inflammatory cells were present in magpie 2 and 6 . There were necrotic villi, numerous, ovoid shaped oocysts and mild mononuclear inflammatory cell infiltrations in propria mucosa of the small intestines of magpie 3 (Fig. 3D). In the liver, multifocal paratyphoid nodules, formed by multifocal hepatocyte necrosis surrounded by degenerate heterophils and macrophages, were observed in magpie 6. Besides, perivascular cuffings with gliosis were detected in the brain.

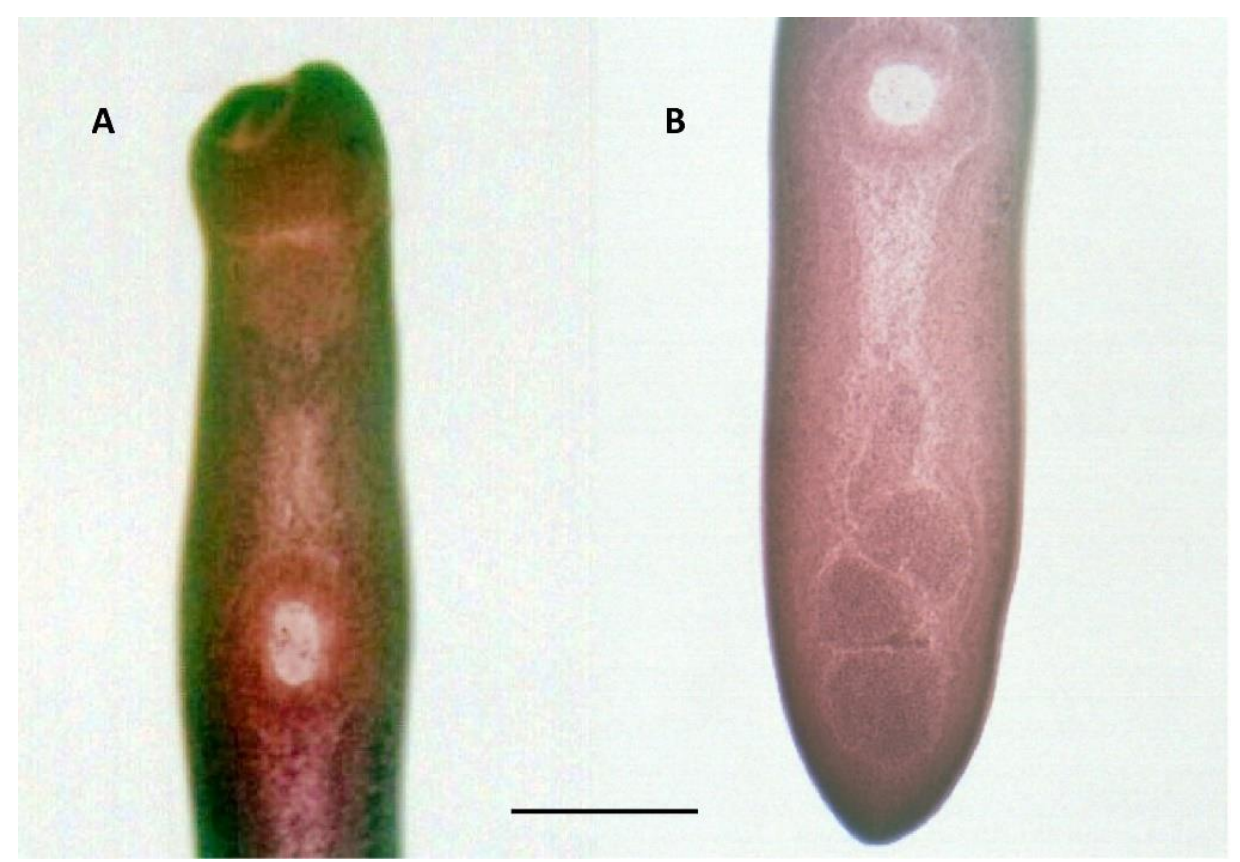

Figure 1. Brachylaima sp. collected from magpie 3. A) Anterior part, B) Posterior part. Bar line shows $0.4 \mathrm{~mm}$.

Şekil 1. Saksağan 3'ten toplanan Brachylaima sp. A) Anterior kısmı, B) Posterior kısmı. Bar çizgisi 0,4 mm’yi göstermektedir. 


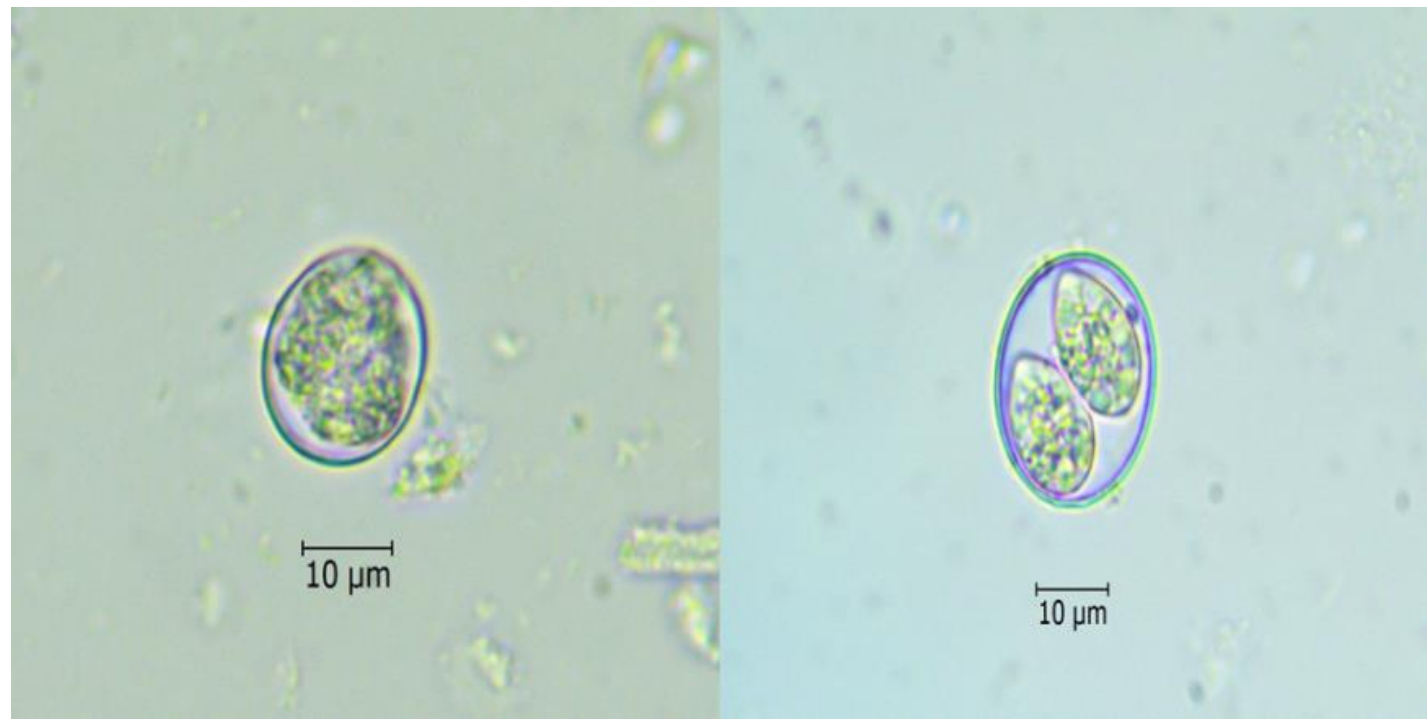

Figure 2. Unsporulated and sporulated (7th day) oocytes of Isospora rochalimai

Şekil 2. Isospora rochalimai'nin sporsuz ve sporlu (7. Gün) ookistleri

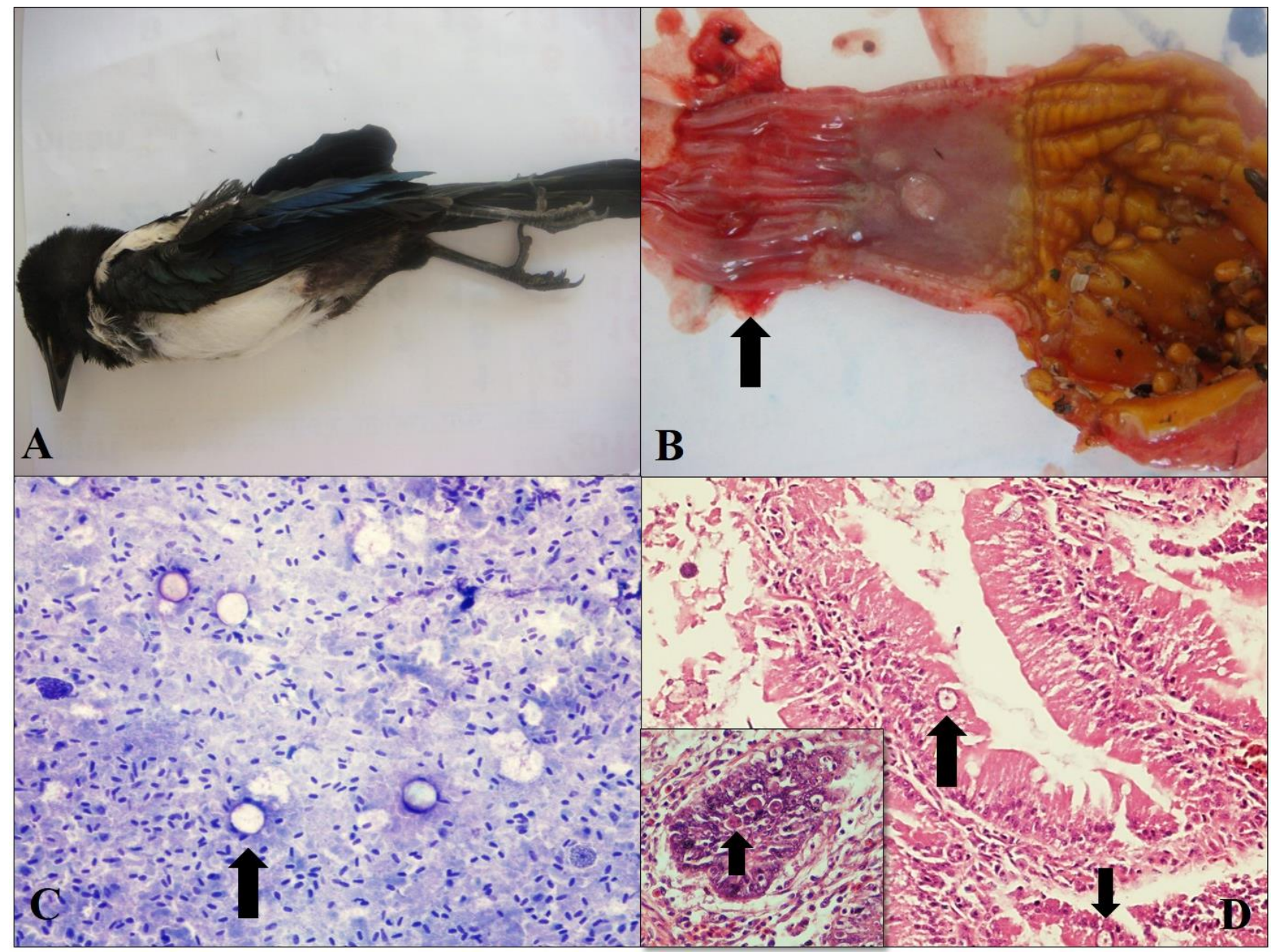

Figure 3. A) External examination of a Magpie (Pica pica). B) Macroscopic photograph of the proventriculus-ventriculus and intestinal mucosa. Haemorrhagic intestinal mucosa due to intestinal coccidiosis. Arrow showed duodenum. C) Touch imprint samples prepared from intestinal mucosa, Hemacolor, 10×. Arrow showed oocysts. D) Histopathologic appearance of the small intestine, H\&E, 20×. Necrotic villi and numerous oocysts (arrows) are observed in the mucosa of the small intestine of magpie 3.

Şekil 3. A) Saksağanın dıștan muayenesi. B) Proventrikülüs-ventrikülüsün ve bağırsak mukozasının makroskobik fotoğrafi. İntestinal coccidiosis nedenli hemorajik intestinal mukoza. Ok, duodenumu göstermektedir. C) Bağırsak mukozasından hazırlanan tuşe preparat, Hemacolor, 10×. Ok, ookistleri göstermektedir. D) İnce bağırsağın histopatolojik görünümü, H\&E, 20×. Nekrotik villi ve çok sayıda ookist (oklar), saksağan 3 'ün ince bağırsak mukozasında gözlenmektedir. 
Table 1. Bacteriologic, parasitologic and histopathologic findings of sampled magpies Tablo 1. Örneklenen saksağanlarda bakteriyolojik, parazitolojik ve histopatolojik bulgular

\begin{tabular}{c|c|c|c}
\hline No. of magpies & Bacteriologic & Parasitologic & Histopathologic findings \\
\hline 1 & Klebsiella pneumonia & - & $\begin{array}{c}\text { Subacute focal necrotic mycotic pneumonia } \\
\text { and subacute diffuse nonpurulent enteritis }\end{array}$ \\
\hline 2 & $\begin{array}{c}\text { Staphylococcus xylosus, } \text { S. } \\
\text { sciuri }\end{array}$ & Passerilepis sp. & $\begin{array}{c}\text { Chronic nonpurulent granulomatous } \\
\text { gastroenteritis }\end{array}$ \\
\hline 3 & - & $\begin{array}{c}\text { Brachylaima } \text { sp., } \\
\text { Isospora rochalimai }\end{array}$ & \begin{tabular}{c} 
Subacute nonpurulent verminous enteritis \\
\hline 4
\end{tabular} \\
\hline 5 & Escherichia coli & - & Nonspecific findings \\
\hline 6 & E. coli & - & Nonspecific findings \\
\hline 7 & Staphylococcus (CONs) & - & $\begin{array}{c}\text { Perivasculer cuffings in brain, cocobacilli in } \\
\text { proventriculus and lumen of convoluted } \\
\text { tubules, subacute multifocal necrotic } \\
\text { granulomatous hepatitis (paratyphoid } \\
\text { nodules), chronic granulamatous enteritis }\end{array}$ \\
\hline 8 & - & - & Nonspecific findings \\
\hline
\end{tabular}

The microbiological tests conducted on eight samples showed those eight pathogenic bacteria and no fungi. Bacteriological identification results for targeted material from magpies were shown in Table 1. Coagulasenegative staphylococci (n: 2, 25\%) (Staphylococcus xylosus and S. sciuri), Escherichia coli (n: 1, 12.5\%) and Klebsiella pneumonia ( $\mathrm{n}: 1,12.5 \%$ ) were the prominent species while Salmonella spp. (n: 1, 12.5\%) was frequently isolated from magpies. The bacteriological cluster represented (n: 6,75\%) bacteria out of 5 different bacterial species from 8 magpies. None of the samples represented Mycoplasma spp., Campylobacter spp. and germs for fungi.

\section{Discussion and Conclusion}

Birds of prey may act as a reservoir for various contagious diseases to human such as Staphylococci, Influenza A virus, West Nile and tick-borne infections (20, $27,34)$. Even though this study was not conducted to detect specifically diseases that can be transmitted to humans or animals, Staphylococcus species and Isospora rochalimai determined in this study can be considered in this group.

In the study, two helminth species and one protozoan species were recovered from common magpies, which is a new record for parasitic studies in Turkey. Parasitologic findings resulted in a diagnosis of these species; this is the first record of Brachylaima sp., Passerilepis sp. and Isospora rochalimai in common magpies from Turkey. Passerilepis is a member of Hymenolepididae, cestodes in this family might induce catarrhal enteritis and necrosis of mucosa (32). Authors were thought that the granulomatous reaction with giant cells of the foreign body-type in magpie 2 arose from reaction to Passerilepis sp. Against some bacterial agents like Mycobacterium avium might develop a few granulomas in the intestines of wild birds. In some reports, tuberculosis and salmonellosis have been shown to be associated with crowding and the contaminated environment in wild birds (31). Salmonella sp. can spread to the liver, leading to toxin-induced necrotic hepatitis known as paratyphoid nodules (16, 24, 31). In our study, isolating Salmonella and Staphylococcus spp. in magpie 6 supports these studies.

All parasite species found in our study have been previously described as parasitising Passerine birds/magpies either on different parts of the world $(8,12$, $35)$ or also from neighbouring countries of Turkey $(14,23$, $25)$. As the parasites of magpies, there is a unique research in Turkey (6). However, researchers have detected different helminth and protozoan species than this study.

The bacteriological composition of the samples showed variability. In this study, coagulase-negative Staphylococcus (CONs) was the predominant species detected from clinical specimens. Staphylococci may be transient contaminants, short-term replicating residents, or long-term colonisers of the skin of animals (29). Most that cause of infection does so when the skin or mucous membranes are compromised in some way. Infections by Staphylococcus often began at some breach of the epithelial barrier, whether keratinized, mucosal or conjunctival body parts. Virulence of Staphylococcus in domestic and wild animals conceived that multifactorial mechanism, such as producing microbial surface components recognizing adhesive matrix molecules (MSCRAMMs). 
Klebsiella pneumonia is an important pathogen of companion and wild birds. The organism is a contaminant of bird seeds, fruits and vegetables. Birds are easily colonized and the microorganisms are frequently isolated from the cloaca and choana of clinically normal birds. Respiratory infections, septicemia, and diarrhea are the common disease manifestations in compromised hosts. While, mycotic infections can be accompanied by immunosuppressive birds $(28,29)$. Although the fungal type in the lung could not be isolated and identificated by mycotic tests, microbiologically isolated K. pneumonia in this study might have been caused of nonpurulent enteritis in magpie 1.

Besides Klebsiella, E.coli infections should be considered as a remarkable Gram-negative pathogen for poultry and wild birds. E.coli occurs naturally in the lower part of intestines of human and warm-blooded animals. Commensal E.coli strains typically do not cause disease. However, they can be opportunistic pathogens when certain conditions exist. Pathogenic E.coli species are broadly grouped into two categories; extraintestinal pathogenic E.coli (UPEC, MNEC), and intestinal (STEC, ETEC, EPEC, EIEC, EAEC) / diarrheagenic E.coli depending on whether they cause disease outside or within the intestinal tract. Extra pathogenic E.coli strains carry a distinct set of virulence genes that enable them to cause disease outside the intestine (16). Avian pathogenic $E$. coli (APEC) caused by extra-intestinal pathogenic $E$. coli strains; is the term used to describe aerosacculitis, polyserositis, septicemia and other mainly extraintestinal diseases in chickens, turkeys and other avian species. APEC is found in the intestinal microflora of healthy birds and most of the diseases associated with them are secondary to environmental and host predisposing factors (9).

A study was conducted in Norway between the periods from 1969 to 2000; Salmonella spp. was isolated from 470 wild birds belonging to 26 species. The salmonella-positive birds included 441 small passerines, 15 gulls, five waterfowl, four birds of prey, three doves, and two crows. Serovar Typhimurium O:4,5,12 was identified as the most common variant found in bird species other than small passerines, mainly gulls, and this variant has been responsible for three large outbreaks of human salmonellosis in Norway (24). It has been suggested that serovar Typhimurium has established a reservoir in avian wildlife, and epidemiological and bacteriological evidence indicate that wild birds may transmit the infection to humans $(17,24)$.

Wild birds have been postulated as sentinels, reservoirs, and potential spreaders of antibiotic resistance through migration can be transmitted from birds to humans and vice versa (4). A research which was conducted between the years 1999-2000; it was found that
Escherichia coli isolates were resistant to multiple antibiotics eight out of 20 magpies trapped and the most prevalent resistance trait among these isolates was to tetracycline, but resistance to ampicillin, chloramphenicol, kanamycin, sulphonamide, tetracycline and trimethoprim were also found (19). In this study, antimicrobial resistance pattern of bacterial isolates detected from magpies was not mentioned. Molecular characterisation of bacteria was not performed, also.

Coccidiosis from the genus Isospora had been reported previously in various wild birds $(3,13)$ and different coccidian species had identified in magpies also (35). Necropsy, histopathological and parasitological findings in our study were consistent with coccidiosis. Due to defined findings for magpie 3 which brought to the hospital with non-traumatic symptoms, coccidiosis was thought to be the cause of its death.

As a conclusion, investigation of these magpies resulted in new infectious agents for Turkey's wildlife fauna with related histopathological findings. Further investigations should be performed to detect if the agents have a potential of bird to animal or zoonotic characters.

\section{References}

1. Anonymus (2011): OIE \& Iowa State University. The Center for Food Security and Public Health \& Institute for International Cooperation in Animal Biologics. Methicillin Resistant Staphylococcus aureus (MRSA), Available at http://www.cfsph.iastate.edu/Factsheets/pdfs/mrsa.pdf (Accessed June 3, 2013).

2. Anonymus (2014): Turkish State Meteorological Service: Meteorological Data in Northwestern Turkey 1954-2015. Available at http://www.dmi.gov.tr/veridegerlendirme/ilve-ilceleristatistik.aspx?m=BURSA (Accessed August 25, 2015).

3. Berto BP, Flausino W, McIntosh D, et al. (2011): Coccidia of New World passerine birds (Aves: Passeriformes): a review of Eimeria Schneider, 1875 and Isospora Schneider, 1881 (Apicomplexa: Eimeriidae). Syst Parasitol, 80, 159 - 204.

4. Bonnedahl J, Järhult JD (2014): Antibiotic resistance in wild birds. J Med Sci, 119(2), 113-116.

5. Bray R, Gibson D, Jones A (2008): Keys to the Trematoda. Vol. 3. London, CAB International.

6. Çetindă̆ M, Bıyıkoğlu G (1997): Occurrence of Dispharynx nasuta (Rudolphi, 1819) and Trichomonas sp. in magpies (Pica pica) in Turkey. Etlik Vet Mikrob Derg, 9(1), 149 - 156. (Turkish with English abstract)

7. De Boer E, Zwartkruis-Nahuis JTM, Wit B, et al. (2009): Prevalence of methicillin-resistant Staphylococcus aureus in meat. Int J Food Microbiol, 134(1), 52-56.

8. Del Campillo MC, Gonzalez MYM (1981): Helmintos y moluscos, con especial atencion a la familia Helicidae. 525 - 539. In: De Campillo MC (Ed), Trabajos del Departamento de Patologia Infecciosa y Parasitaria (1954 1979). Facultad de Veterinaria de la Universidad de Leon. (Spanish) 
9. Dho-Moulin M, Fairbrother JM (1999): Avian pathogenic Escherichia coli (APEC). Vet Res, 30(2-3), 299316.

10. Duszynski DW, Upton SJ, Couch L (2000): The Coccidia of the World. Department of Biology, University of New Mexico. Available at http://biology.unm.edu/biology/ coccidia/home.html. (Accessed August 14, 2014).

11. Gibson D, Jones A, Bray R (2002): Keys to the Trematoda. Vol. 1. London, CAB International.

12. Gigon P, Beuret J (1991): Contribution a la connaissance des helmintes d'oiseaux dans le nord - ouest de la Suisse. Rev Suisse Zool, 98(2), 279 - 302. (French)

13. Greiner EC (2008): Isospora, Atoxoplasma, and Sarcocystis. 108-119. In: Atkinson CT, Thomas NJ, Hunter DB (Eds), Parasitic Diseases of Wild Birds. John Wiley and Sons Inc, USA.

14. Halajian A, Eslami A, Mobedi I, et al. (2011): Gastrointestinal helminths of Magpies (Pica pica), Rooks (Corvus frugilegus) and Carrion Crows (Corvus corone) in Mazandaran Province, North of Iran. Iranian J Parasitol, 6(2), $38-44$.

15. Harrison C, Greensmith A (1993): Birds of the World. Kindersley Inc., USA.

16. Jorgensen JH, Pfaller MA, Carrol KC, et al. (2015): Manual of Clinical Microbiology. $11^{\text {th }}$ Edition, Section II, Bacteriology, Gram Negative Bacteria, Esherichia, Shigella and Salmonella. ASM Press, Washington DC.

17. Kapperud G, Gustavsen S, Hellesnes I, et al. (1990): Outbreak of Salmonella typhimurium infection traced to contaminated chocolate and caused by a strain lacking the 60-megadalton virulence plasmid. J Cli Microbiol, 28(12), 2597-2601.

18. Krone O, Cooper JE (2002): Parasitic disease. 105-120. In: Cooper JE (Ed), Birds of Prey Health and Diseases. 3rd ed. Oxford, UK: Blackwell Science.

19. Livermore DM, Warner M, Hall L, et al. (2001): Antibiotic resistance in bacteria from magpies (Pica pica) and rabbits (Oryctolagus cuniculus) from west Wales. Environ Microbiol, 3(10), 658-661.

20. Moskvitina NS, Korobitsyn IG, Tyutenkov OY, et al. (2014): The role of birds in the maintenance of tick-borne infections in the Tomsk Anthropurgic Foci. Ecology, 4, 408414.

21. Porrero MC, Mentaberre G, Sánchez S, et al. (2013): Methicillin resistant Staphylococcus aureus (MRSA) carriage in different free-living wild animal species in Spain. Vet J, 198(1), 127 - 30.

22. Quinn PJ, Carter ME, Markey B et al. (2000): Clinical Veterinary Microbiology. Section 2: Bacteriology, 8: Staphylococcus species. Harcourt Publishers Limited.

23. Rahemo ZIF, Zangana FM, Al-Kattan FM (2001): The Cestodarian and Acanthocephalan worms from the bird, Sturnus vulgaris. Acta Parasitol Turcica, 25(3), 317 - 318.
24. Refsum T, Handeland K, Baggesen DL, et al. (2002): Salmonellae in avian wildlife in Norway from 1969 to 2000. Appl Environ Microbiol, 68(11), 5595-5599.

25. Schmidt GD, Greenberg Z, Wertheim G (1985): Tapeworms from Turkey and Syria in the collection of the late George G. Witenberg. Proc Helminthol Soc Wash, 52(2), $312-313$.

26. Schmidt GD (1986): Handbook of tapeworm identification. Boca Raton, Florida, CRC Press.

27. Slusher MJ, Wilcox BR, Lutrell MP, et al. (2014): Are Passerine birds reservoirs for Influenza a viruses? J Wildlife Dis, 50(4), 792 - 809.

28. Songer Glenn J, Post Karen W (2005a): Veterinary Microbiology, Bacterial and Fungal Agents of Animal Diseases, Section 2, Veterinary Bacteriology. Chapter 14, Miscellaneous Coliforms: The Genera Klebsiella, Enterobacter and Citrobacter. Elsevier Saunders.

29. Songer Glenn J, Post Karen W (2005b): Veterinary Microbiology, Bacterial and Fungal Agents of Animal Diseases, Section 2, Veterinary Bacteriology. Chapter 4, Gram Positive Aerobic Cocci. Elsevier Saunders.

30. Sousa M, Silva N, Igrejas G, et al. (2014): Antimicrobial resistance determinants in Staphylococcus spp. recovered from birds of prey in Portugal. Vet Microbiol, 171, 426440.

31. Stroud RK, Thoen CO, Duncan RM (1986): Avian Tuberculosis and Salmonellosis in a Whooping Crane (Grus americana). J Wildlife Dis, 22(1), 106-110.

32. Taylor MA, Coop RL, Wall RL (2007): Veterinary Parasitology, Blackwell Publishing, Third Edition.

33. Tolgay N (1973). Evcil ve yabani kanatlların önemli parazitleri. Ankara Üniversitesi Veteriner Fakültesi Yayınları 294/195, Ankara Üniversitesi Basımevi. (Turkish).

34. Tsiodras S, Kelesidis T, Kelesidis I, et al. (2008): Human infections associated with wild birds. J Infection, 56: 83 98.

35. Upton SJ, Langen TA, Wright TF (1995): A new species of lsospora Schneider, 1881 (Apicomplexa: Eimeriidae) from the white - throated magpie jay Calocitta formosa (Passeriformes: Corvidae) from Costa Rica. Syst Parasitol, 31: 195-199.

36. Yamaguti S (1958): Systema Helminthum. Vol. I. The Digenetic Trematodes of Vertebrates. Interscience Publishers, New York.

37. Yamaguti S (1971): Synopsis of digenetic Trematodes of vertebrates. Vols. 1 and 2, Keigaku Publishing, Tokyo.

Geliş tarihi: 18.03.2018 / Kabul tarihi: 19.07.2018
Address for correspondence:
Assoc. Prof. Dr. Ahmet Onur GIRISSGIN
Bursa Uludag University, Veterinary Faculty
Department of Parasitology, Bursa, Turkey
e-mail: onurgirisgin@gmail.com 